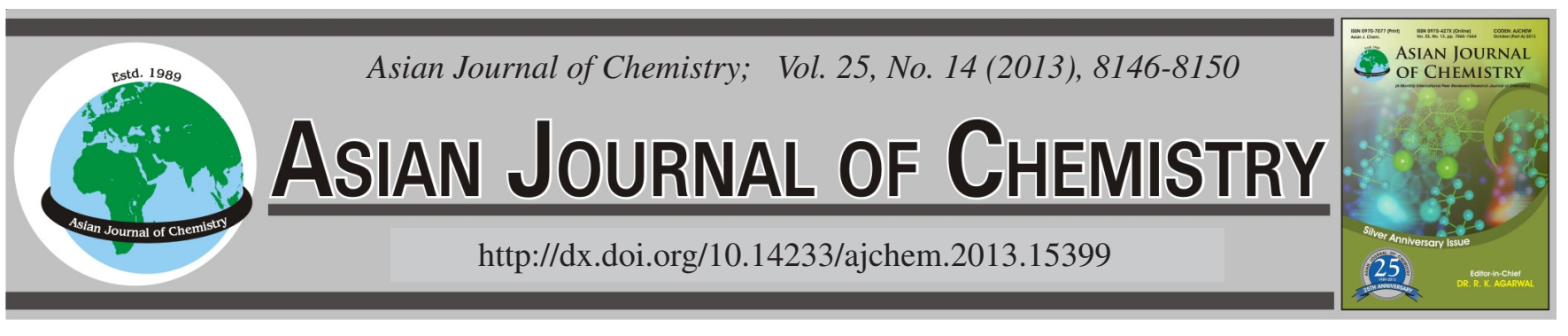

\title{
Synthesis of Peony-Like Cu(II) Complexes of Schiff Base Derived from 3,4-Dimethoxybenzaldehyde and $p$-Aminobenzoic Acid
}

\begin{abstract}
Qiang Xu, Yan-Hua CaI ${ }^{*}$ and Feng Wang
School of Materials and Chemical Engineering, Chongqing University of Arts and Sciences, Yongchuan 402160, Chongqing, P.R. China

*Corresponding author: E-mail: caiyh651@yahoo.com.cn

(Received: 28 February 2013;

Accepted: 5 August 2013)

AJC-13892

Peony-like $\mathrm{Cu}(\mathrm{II})$ complexes of Schiff base was synthesized by copper acetate. Schiff base ligand was synthesized by $3,4-$ dimethoxybenzaldehyde with $p$-aminobenzoic acid using supersonic speed gas impacting. The synthesized peony-like $\mathrm{Cu}$ (II) complexes of Schiff base were characterized by Fourier transform infrared spectroscopy, scanning electron microscopy and thermo-gravimetric analysis. SEM exhibited that the $\mathrm{Cu}(\mathrm{II})$ complexes of Schiff base was uniform and the diameter of the peony-like Cu(II) complexes of Schiff base was $c a .10 \mu \mathrm{m}$, analysis results reveal that surfactants CTAB plays an interacting important role in the formation of peony-like $\mathrm{Cu}$ (II) complexes of Schiff base. TGA indicated that $\mathrm{Cu}$ (II) complexes of Schiff base was divided into two steps and the decomposition temperature increased with the increasing of heating rate. The optimized reaction condition was stirring speed $20 \mathrm{rpm}$, molar ratio of Schiff base ligand: copper acetate $1: 3$, reaction time $3 \mathrm{~h}$, reaction temperature $70{ }^{\circ} \mathrm{C}$, the yield was $90.7 \%$.
\end{abstract}

Key Words: Complexes, Schiff base, Morphology, Cetyltrimethyl ammonium bromide.

ᄂ _ - - - - _ - - - - - - - - - - - - - - - - - - - - - - -

\section{INTRODUCTION}

Schiff bases and their metal complexes have been continuous received intensively attentions not only due to the easy with which they can be synthesized ${ }^{1}$, but also owing to their widely range of potential applications in co-ordination chemistry $^{2,3}$, medicinal chemistry ${ }^{4-6}$, catalysis ${ }^{3,7-9}$, optical and magnetic materials ${ }^{10,11}$.

Schiff base ligands can coordinate with metal ions (transition- or alkali-) to form various Schiff base chelating complexes through $\mathrm{O}-, \mathrm{N}$-donors on the imino groups $(-\mathrm{C}=\mathrm{N}-)^{7}$. These ligands have shown fascinating properties in antimicrobial $^{4}$, antifungal ${ }^{5}$, anticancerous ${ }^{12,13}$ and antiproliferative activities ${ }^{6}$. For example, Shebl et al. ${ }^{4}$ reported that $\mathrm{Co}(\mathrm{II}), \mathrm{Ni}(\mathrm{II})$ and $\mathrm{Cu}(\mathrm{II})$ of mono-, bi-and tri-nuclear metal complexes of a new Schiff base ligand was found to be biologically active. They showed high antimicrobial activity against gram positive bacteria, gram negative bacteria and fungi. Arjmand et al. ${ }^{6}$ synthesized a new chiral heterocyclic Schiff base moduted $\mathrm{Cu}$ (II) complexes, which exhibited a remarkable DNA cleavage activity with CT-DNA in presence of different activators compare to classical anticancer drug cisplatin. And also, flexible catalysis are exhibited by varieties of metal complexes of Schiff bases. A new oxovanadium(IV) was investigated by Grivani et al. ${ }^{9}$ which was very active and selective in the epoxidation of cyclooctene under optimized condition.
Up to now, literatures ${ }^{1,3,5,7}$ reported the synthesis and applications of various meatal complexes of Schiff bases. However, the morphology of Schiff base complexes was little investigated. Thus, in this paper, we synthesized the Schiff base derived from 3,4-dimethoxybenzaldehyde and $p$-aminobenzoic acid by a novel solvent-free synthesis method using supersonic speed gas impacting and the $\mathrm{Cu}(\mathrm{II})$ complexes of Schiff base derived from 3,4-dimethoxybenzaldehyde and $p$-aminobenzoic acid was fabricated by liquid-state reaction and their structures were characterized by Fourier transform infrared spectroscopy and ${ }^{1} \mathrm{H}$ nuclear magnetic resonance. The morphology of $\mathrm{Cu}$ (II) complexes of Schiff base derived from 3,4-dimethoxybenzaldehyde and $p$-aminobenzoic acid was observed by scanning electron microscopy, the optimum reaction conditions was investigated and obtained. The possible formation mechanism of peony-like $\mathrm{Cu}$ (II) complexes of Schiff base was discussed.

\section{EXPERIMENTAL}

The materials used in this study were of analytical grade (AR) grade. 3,4-Dimethoxybenzaldehyde, $p$-aminobenzoic acid were procured from Beijing Chemical Reagents Company (Beijing, Chian) and Chengdu Kelong Chemical Reagents Company, respectively and copper acetate, cetyltrimethyl ammonium bromide (CTAB) and N,N-dimethylacetamide were procured from Mianyang Rongshen Chemical Reagents Company (Sichuan Province, China). 
Synthesis of Schiff base derived from 3,4-dimethoxybenzaldehyde and $\boldsymbol{p}$-aminobenzoic acid (Scheme-I): Schiff base derived from 3,4-dimethoxybenzaldehyde and $p$ aminobenzoic acid was prepared as follows: 3,4-dimethoxybenzaldehyde and $p$-aminobenzoic acid, in a 1:1 molar ratio, were mixed and the specific reaction process have described in previous paper ${ }^{14-16}$. The product was collected after quantitative reaction and dried in a vacuum at $60^{\circ} \mathrm{C}$. IR $\left(\mathrm{KBr}, \mathrm{v}_{\max }\right.$, $\left.\mathrm{cm}^{-1}\right)$ : 3455.1, 2836.2, 1674.4, 1625.9, 1577.3, 1510.1, 1452.7, 809.5, 771.9; ${ }^{1} \mathrm{H}$ NMR (DMSO, $\left.500 \mathrm{MHz}, \mathrm{ppm}\right) \delta: 12.06$ (s, $1 \mathrm{H}, \mathrm{COOH}), 8.54(\mathrm{~s}, 1 \mathrm{H}, \mathrm{CH}=\mathrm{N}), 6.58-7.63(\mathrm{~m}, 7 \mathrm{H}, \mathrm{Ar}), 3.86$ $\left(\mathrm{s}, 6 \mathrm{H}, \mathrm{OCH}_{3}\right)$.

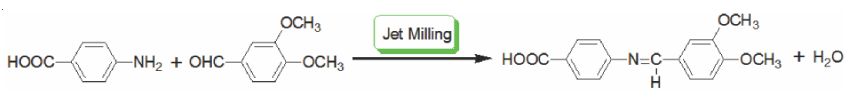

Scheme-I: Synthesis of Schiff base derived from 3,4dimethoxybenzaldehyde and $p$-aminobenzoic acid

Synthesis of $\mathrm{Cu}(\mathrm{II})$ complexes of Schiff base: Schiff base derived from 3,4-dimethoxybenzaldehyde and $p$-aminobenzoic acid, CTAB and $50 \mathrm{~mL} \mathrm{~N}, \mathrm{~N}$-dimethylacetamide were mixed and copper acetate solution was added slowly into the mixture, the precipitate occurred immediately. Then the mixture was heated up to $60-80{ }^{\circ} \mathrm{C}$ and held for $2-4 \mathrm{~h}$ with stirring. Obtained precipitate was washed by $300 \mathrm{~mL}$ water for 4 times at room temperature. The resulting product was dried in vacuum at $65^{\circ} \mathrm{C}$. The structure of synthesized $\mathrm{Cu}(\mathrm{II})$ complexes of Schiff base is shown in Fig. 1. IR ( $\mathrm{KBr}, \mathrm{v}_{\max }$, $\left.\mathrm{cm}^{-1}\right)$ : 3434.2, 3250.8, 3141.7, 2855.8, 1621.3, 1606.5, 1573.4, 1537.1, 1507.9, 1433, 1389.6, 1125.2, 1095.2, 778.1, 518.5, 444.3.

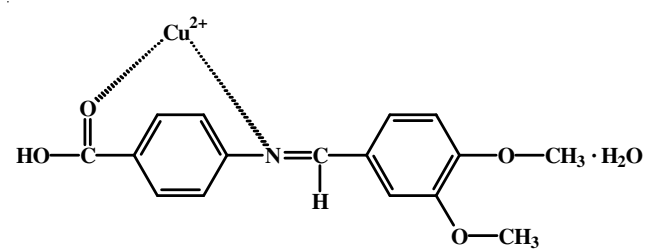

Fig. 1. Structure of $\mathrm{Cu}(\mathrm{II})$ complexes of Schiff base

Characterization: The ${ }^{1} \mathrm{H}$ nuclear magnetic resonance of Schiff base derived from 3,4-dimethoxybenzaldehyde and $p$-aminobenzoic acid was recorded on Brucker AVANCE 300 spectrometers. The solvent was dimethyl sulphoxide (DMSO). Fourier transform infrared spectra were recorded on a BioRad FTS135 spectrophoto-meter from $4000-400 \mathrm{~cm}^{-1}$. The sample were mixed with $\mathrm{KBr}$ powders and pressed into a disk suitable for IR measurement.

The morphologies of $\mathrm{Cu}$ (II) complexes of Schiff base was examined by XL-30 ESEM FEG, Philips, in 15-20 kV accelerating voltage (Tungsten filament).

TGA thermal analyzer was performed using a simultaneous thermal analysis Q500 (TA instrument USA) with a heating ramp of $5,10,15$ and $20^{\circ} \mathrm{C} / \mathrm{min}$ under nitrogen flow (50 $\mathrm{mL} / \mathrm{min}$ ) from $40-500{ }^{\circ} \mathrm{C}$.

\section{RESULTS AND DISCUSSION}

Morphology of $\mathrm{Cu}(\mathrm{II})$ complexes of Schiff base and probable formation mechanism: The morphology of the synthesized $\mathrm{Cu}(\mathrm{II})$ complexes of Schiff base sample was analyzed by the SEM as shown in Fig. 2. The lower magnification image in Fig. 2a-b indicates that the $\mathrm{Cu}$ (II) complexes of Schiff base is uniform and $\mathrm{Cu}$ (II) complexes of Schiff base do not agglomerate. The peony-like $\mathrm{Cu}$ (II) complexes of Schiff base can be observed from the higher magnification image in Fig. 2-d, which clearly shows that the $\mathrm{Cu}$ (II) complexes of Schiff base flower with peony-like structure are composed of many triangle shape $\mathrm{Cu}$ (II) complexes of Schiff base sheets. The diameter of the peony-like $\mathrm{Cu}$ (II) complexes of Schiff base is $c a .10 \mu \mathrm{m}$. In addition we can also observe the thichness of the triangle shape $\mathrm{Cu}$ (II) complexes of Schiff base sheets is $0.15-0.2 \mu \mathrm{m}$. However, we also observe that there existed a little imperfect peony-like $\mathrm{Cu}$ (II) complexes of Schiff base in Fig. 2c, resulting from the formation mechanism of $\mathrm{Cu}$ (II) complexes of Schiff base, meanwhile, which also indicates the importance of reaction condition.
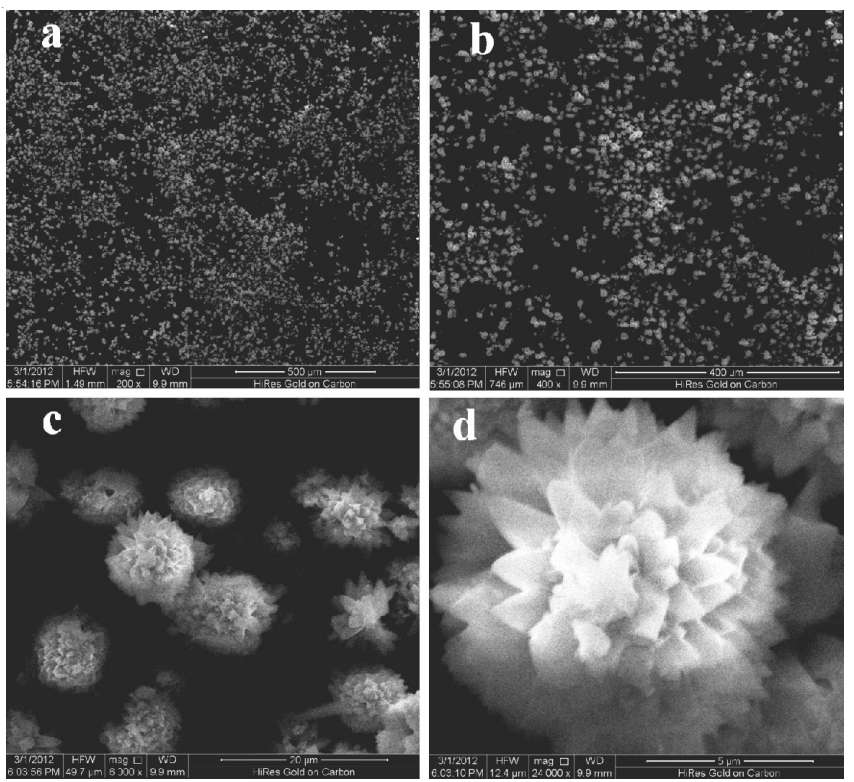

Fig. 2. SEM of $\mathrm{Cu}(\mathrm{II})$ complexes of Schiff base

As to the formation mechanism of specific morphology compound, the formation mechanisms were different when different preparation methods were used. Up to now, there existed many literatures ${ }^{17,18}$ which reported synthesis of specific morphology compound by addition of surfactants. It is suggested that the surfactants play very important roles in the formation of specific morphology compound and surfactants serve as a template in the formation of peony-like $\mathrm{Cu}$ (II) complexes of Schiff base. Fig. 3 showed the probable formation mechanisms of peony-like $\mathrm{Cu}$ (II) complexes of Schiff base. The shciff base ligand was dispersed uniformly in solution with CTAB during the initial stages, the electrostatic repulsion occurred when copper acetate solution was added into the Schiff base ligand solution in stage 2 , which made $\mathrm{Cu}$ (II) complexes not get together each other, resulting in the formation of peony-like $\mathrm{Cu}(\mathrm{II})$ complexes in stage 3.

Reaction conditions of $\mathbf{C u}$ (II) complexes of Schiff base: The influence of the reaction ratio, reaction time, stirring speed and reaction temperature to the yield of $\mathrm{Cu}$ (II) complexes of Schiff base was investigated. Factors and level of experiment 


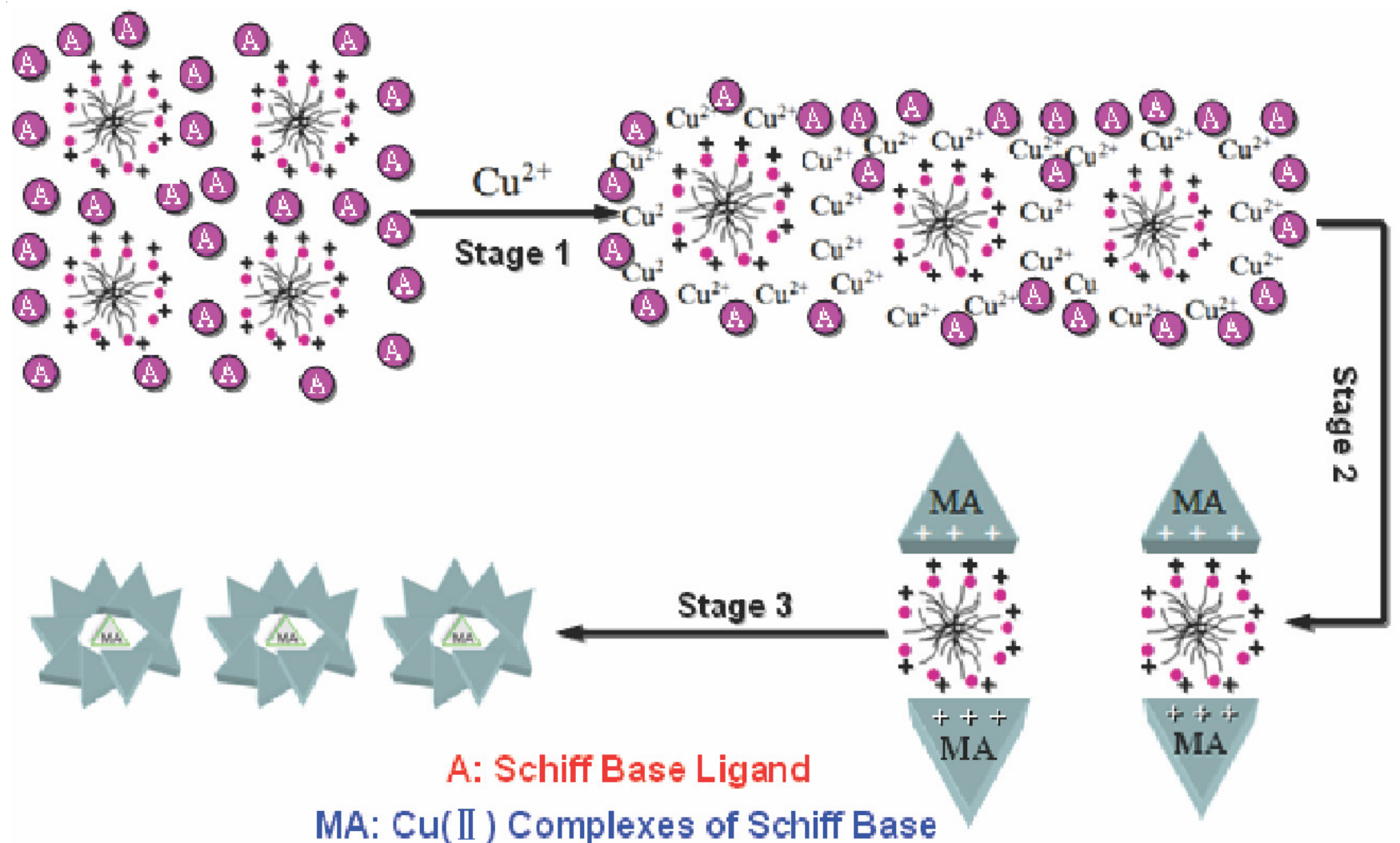

Fig. 3. Schematic illustration of probable formation process of peony-like $\mathrm{Cu}$ (II) complexes of Schiff base

are listed in Table-1 and the results are listed in Table-2. As seen in Table-2. It is clear that stirring speed is more important to yield than other factors. The possible reason is that the stirring speed influences the concentration of interface of Schiff base ligand and copper acetate. According to the experiment, the optimized reaction condition is stirring speed $20 \mathrm{rpm}$, molar ratio of Schiff base ligand: copper acetate 1:3, reaction time $3 \mathrm{~h}$, reaction temperature $70^{\circ} \mathrm{C}$, the yield is $90.7 \%$ under the optimized reaction condition.

Thermal property of $\mathrm{Cu}$ (II) complexes of Schiff base: The thermal property of $\mathrm{Cu}$ (II) complexes of Schiff base was studied by thermo-gravimetric analysis in the $\mathrm{N}_{2}$ flowing atmosphere with the heating rate of $10^{\circ} \mathrm{C} / \mathrm{min}$ from $40-500{ }^{\circ} \mathrm{C}$. As evident from Fig. 4, the TGA curve of $\mathrm{Cu}$ (II) complexes of Schiff base can be divided into two steps of weight loss at the heating rate of $10{ }^{\circ} \mathrm{C} / \mathrm{min}$. The weight loss of $3.1 \%$ during the first step should correspomd to the coordination water molecules. The following the loss of $54.8 \%$ is attributed to the loss of the Schiff base ligand. Fig. 5 also shows that there exist only one stage during $40-500{ }^{\circ} \mathrm{C}$ and there exist different weight loss between $\mathrm{Cu}(\mathrm{II})$ complexes of Schiff base and Schiff

\begin{tabular}{ccccc}
\multicolumn{6}{c}{ TABLE-1 } \\
\hline \multirow{3}{*}{ Level } & \multicolumn{5}{c}{ FACtor } \\
\cline { 2 - 5 } & $\begin{array}{c}\text { Stirring speed } \\
\text { (A) }(\mathrm{r} / \mathrm{min})\end{array}$ & $\begin{array}{c}\text { Reaction } \\
\text { ratio }^{\mathrm{a}}(\mathrm{B})\end{array}$ & $\begin{array}{c}\text { Reaction } \\
\text { time }(\mathrm{C})(\mathrm{h})\end{array}$ & $\begin{array}{c}\text { Reaction temp. } \\
\text { (D) }\left({ }^{\circ} \mathrm{C}\right)\end{array}$ \\
\hline 1 & 10 & $1: 1$ & 2 & 60 \\
2 & 15 & $1: 2$ & 3 & 70 \\
3 & 20 & $1: 3$ & 4 & 80 \\
\hline${ }^{a}$ Schiff base ligand: copper acetate &
\end{tabular}

\begin{tabular}{cccccc}
\multicolumn{7}{c}{ TABLE-2 } \\
\hline \multirow{7}{*}{ Run } & $\begin{array}{c}\text { Stirring } \\
\text { speed (A) }\end{array}$ & $\begin{array}{c}\text { Reaction } \\
\text { ratio (B) }\end{array}$ & $\begin{array}{c}\text { Reaction } \\
\text { time }(\mathrm{C})\end{array}$ & $\begin{array}{c}\text { Reaction } \\
\text { temp. (D) }\end{array}$ & $\begin{array}{c}\text { Yield } \\
(\%)\end{array}$ \\
\hline 1 & $\mathrm{~A}_{1}$ & $\mathrm{~B}_{1}$ & $\mathrm{C}_{1}$ & $\mathrm{D}_{1}$ & 63.4 \\
2 & $\mathrm{~A}_{1}$ & $\mathrm{~B}_{1}$ & $\mathrm{C}_{1}$ & $\mathrm{D}_{2}$ & 69.1 \\
3 & $\mathrm{~A}_{1}$ & $\mathrm{~B}_{1}$ & $\mathrm{C}_{1}$ & $\mathrm{D}_{3}$ & 60.4 \\
4 & $\mathrm{~A}_{1}$ & $\mathrm{~B}_{1}$ & $\mathrm{C}_{1}$ & $\mathrm{D}_{2}$ & 80.0 \\
5 & $\mathrm{~A}_{1}$ & $\mathrm{~B}_{2}$ & $\mathrm{C}_{1}$ & $\mathrm{D}_{2}$ & 57.9 \\
6 & $\mathrm{~A}_{1}$ & $\mathrm{~B}_{3}$ & $\mathrm{C}_{1}$ & $\mathrm{D}_{2}$ & 82.2 \\
7 & $\mathrm{~A}_{1}$ & $\mathrm{~B}_{3}$ & $\mathrm{C}_{1}$ & $\mathrm{D}_{2}$ & 82.3 \\
8 & $\mathrm{~A}_{1}$ & $\mathrm{~B}_{3}$ & $\mathrm{C}_{2}$ & $\mathrm{D}_{2}$ & 85.7 \\
9 & $\mathrm{~A}_{1}$ & $\mathrm{~B}_{3}$ & $\mathrm{C}_{3}$ & $\mathrm{D}_{2}$ & 72.1 \\
10 & $\mathrm{~A}_{1}$ & $\mathrm{~B}_{3}$ & $\mathrm{C}_{2}$ & $\mathrm{D}_{2}$ & 51.6 \\
11 & $\mathrm{~A}_{2}$ & $\mathrm{~B}_{3}$ & $\mathrm{C}_{2}$ & $\mathrm{D}_{2}$ & 72.8 \\
12 & $\mathrm{~A}_{3}$ & $\mathrm{~B}_{3}$ & $\mathrm{C}_{2}$ & $\mathrm{D}_{2}$ & 90.7 \\
\hline
\end{tabular}

base ligand at the same heating rate, the difference of weight loss is $25.7 \%$ which is different from the weight loss between Schiff base ligand and $\mathrm{Cu}$ (II) complexes of Schiff base, resulting from carbonization of the Schiff base ligand at $\mathrm{N}_{2}$ atmosphere. However, these results confirm the structure of $\mathrm{Cu}$ (II) complexes of Schiff base again. Meantime, as shown in Fig. 4, we also observe that the decomposition temperature increases with the increasing of heating rate, the reason is that rapid heating rate makes decomposition of $\mathrm{Cu}$ (II) complexes of Schiff base not achieve at set temperature, at the same time, the temperature has get into the following set temperature, resulting in decomposition achieving at higher temperature. This result is consistent with that of other organic compound $^{19,20}$. 


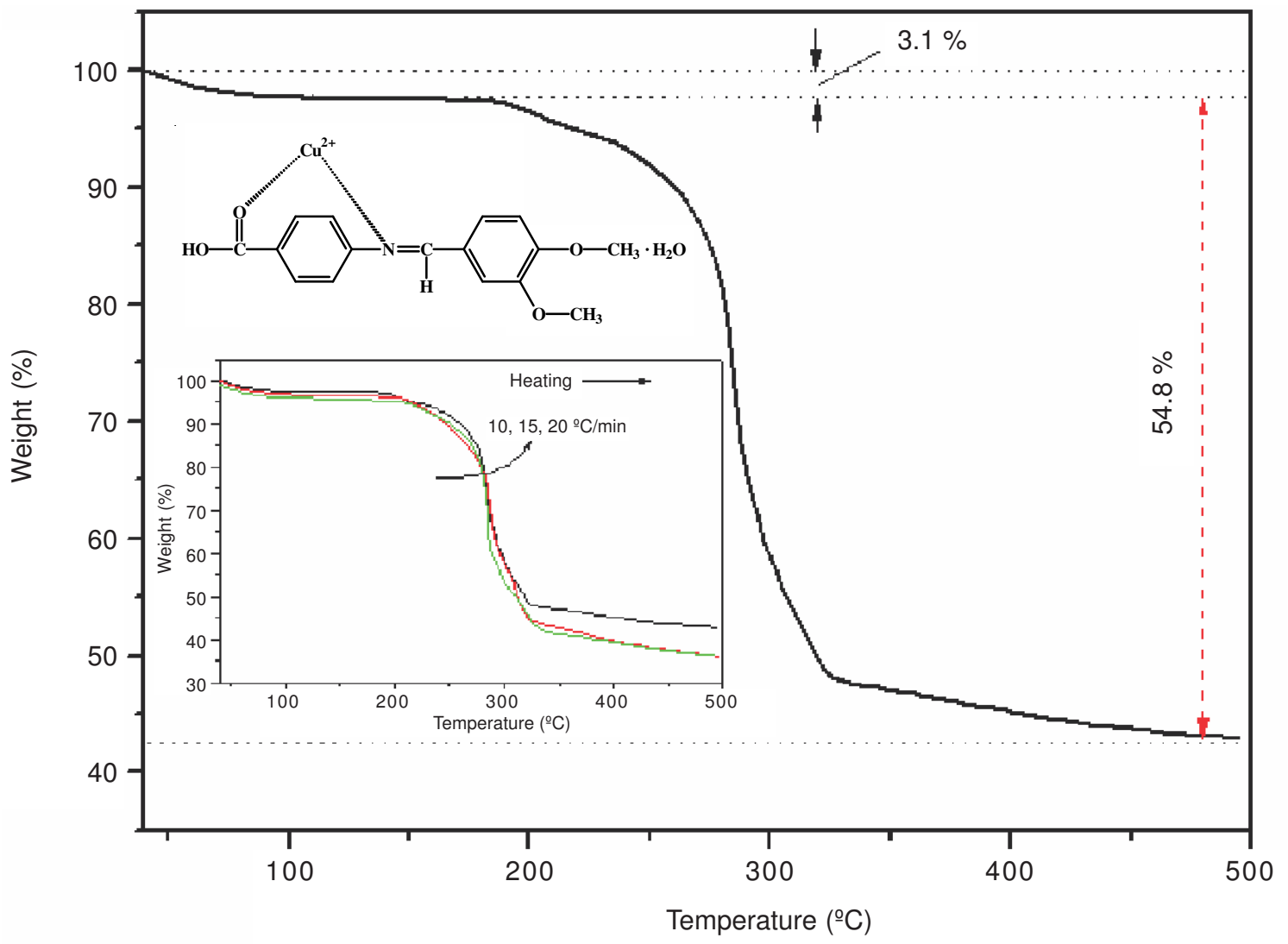

Fig. 4. TGA curves of $\mathrm{Cu}(\mathrm{II})$ complexes of Schiff base at different heating rate

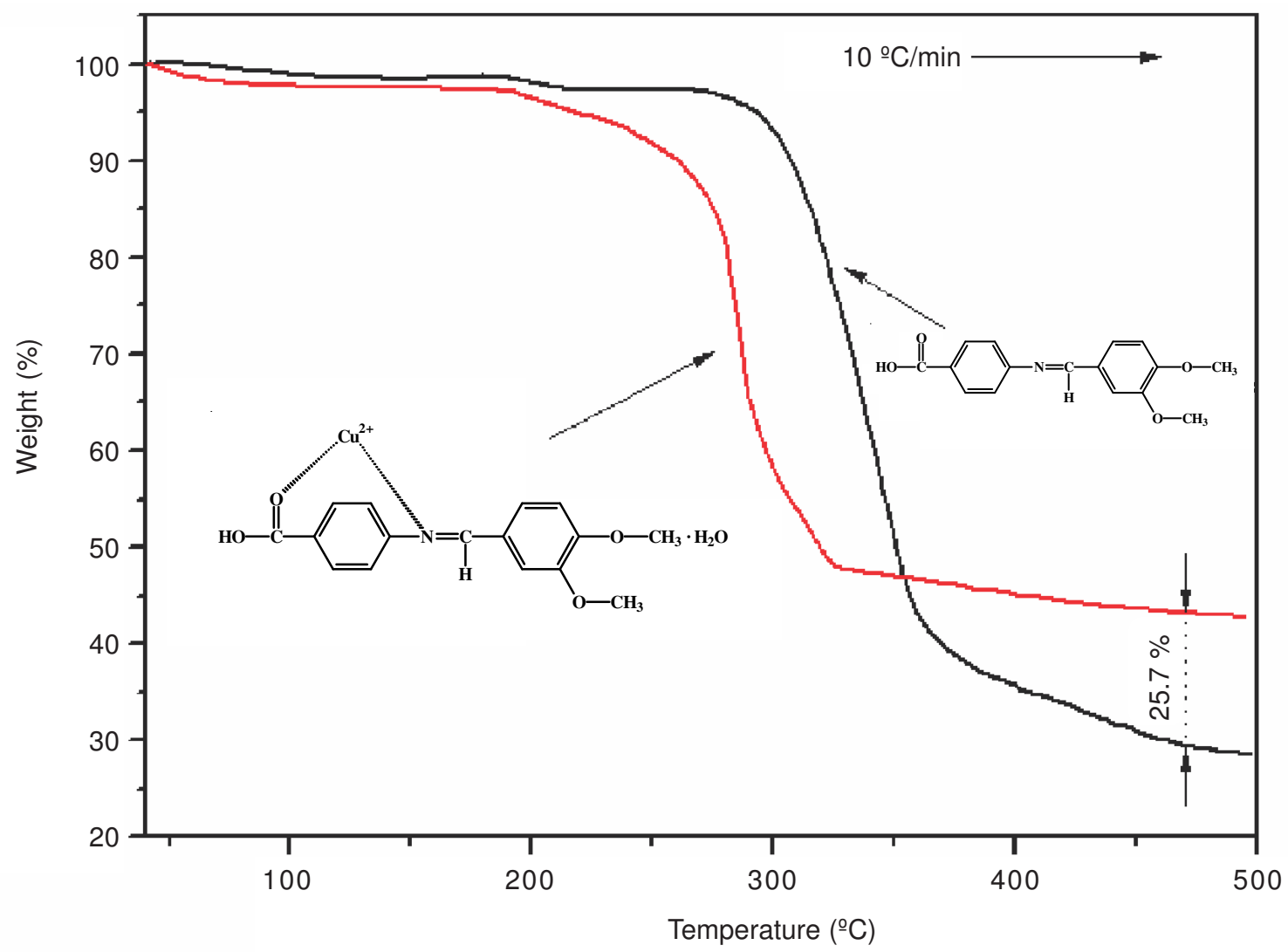

Fig. 5. TGA curves of $\mathrm{Cu}(\mathrm{II})$ complexes of Schiff base and Schiff base ligand 


\section{Conclusion}

Peony-like $\mathrm{Cu}$ (II) complexes of Schiff base was synthesized by $\mathrm{CuSO}_{4}$ and Schiff base ligand as raw materials. SEM exhibited that the $\mathrm{Cu}$ (II) complexes of Schiff base was uniform and the diameter was $c a .10 \mu \mathrm{m}$, Analysis results reveal that surfactants CTAB play important roles in the formation of peony-like $\mathrm{Cu}$ (II) complexes of Schiff base and a probable formation mechanism is proposed. The optimum reaction conditions was investigated and the yield of peony-like $\mathrm{Cu}(\mathrm{II})$ complexes of Schiff base was $90.7 \%$ under the optimized reaction condition. TGA indicated that $\mathrm{Cu}$ (II) complexes of Schiff base was divided into two steps.

\section{ACKNOWLEDGEMENTS}

This work was supported by National Nature Science Foundation of China (Project No. 21101136), Key Project of Chinese Ministry of Education (Project No. 212144), China Postdoctoral Science Foundation (Project No. 2013M531937), Natural Science Foundation Project of CQ CSTC (Project No. cstc2012jjA50001), Postdoctoral Science Foundation Project of ChongQing (Project No. XM20120035), Foundation of ChongQing Municipal Education Commission (Project No. KJ131202) and ChongQing University of Arts and Sciences (Project No. R2012CH10, 2012PYXM04).

\section{REFERENCES}

1. S. Chattopadhyay, P. Chakraborty, Michael G.B. Drew and A. Ghosh, Inorg. Chim. Acta, 362, 502 (2009).

2. R.H. Holm, J. Am. Chem. Soc., 82, 5632 (1960).

3. A. Abu-Surrah, K.A. Ibrahim, M.Y. Abdalla and A.A. Issa, J. Polym. Res., 18, 59 (2011).

4. M. Shebl, S.M.E. Khalil, S.A. Ahmed and H.A.A. Medien, J. Mol. Struct., 980, 39 (2010).

5. K. Singh, M.S. Barwa and P. Tyagi, Eur. J. Med. Chem., 41, 147 (2006).

6. F. Arjmand, F. Sayeed and M. Muddassir, J. Photochem. Photobiol. B, 103, 166 (2011).

7. K.C. Gupta and A.K. Sutar, Coord. Chem. Rev., 252, 1420 (2008).

8. L.I. Rodionova, A.V. Smirnov, N.E. Borisova, V.N. Khrustalev, A.A. Moiseeva and W. Grünert, Inorg. Chim. Acta, 392, 221 (2012).

9 G. Grivani, G. Bruno, H.A. Rudbari, A.D. Khalaji and P. Pourteimouri, Inorg. Chem. Commun., 18, 15 (2012).

10. T. Akitsu and Y. Einaga, Inorg. Chem. Commun., 9, 1108 (2006).

11 P.G. Cozzi, L.S. Dolci, A. Garelli, M. Montalti, L. Prodi and N. Zaccheroni, New J. Chem., 27, 692 (2003).

12. S. Chandra and L.K. Gupta, Spectrochim. Acta A, 61, 269 (2005).

13. A.A. Osowole, I. Ott and O.M. Ogunlana, Int. J. Inorg. Chem., 1 (2012).

14. Y.H. Cai, Asian J. Chem., 24, 4468 (2012).

15. Y.H. Cai, R.F. Peng and S.J. Chu, Asian J. Chem., 22, 5835 (2010).

16. Y.H. Cai, R.F. Peng and S.J. Chu, South Afri. J. Chem., 61, 112 (2008).

17. F. Mohandes and M. Salavati-Niasari, Ultrason. Sonochem., 20, 354 (2012).

18. Z. Khan, O. Bashir, J.I. Hussain, S. Kumar and R. Ahmad, Colloid. Surf. B, 98, 85 (2012).

19. Y.H. Cai, Asian J. Chem., 23, 2622 (2011).

20. S.J. Li and Y.H. Cai, Asian J. Chem., 23, 2619 (2011). 